\title{
Upaya Dinas Pariwisata Dan Kebudayaan Dalam Meningkatkan Kunjungan Wisatawan Di Daya Tarik Wisata Pura Kehen Kabupaten Bangli
}

Ni Luh Putu Krisna Prawami a, 1, Ida Ayu Suryasih a, 2

${ }^{1}$ krisnaprawami18@gmail.com,2idaayusuryasih@unud.ac.id

a Program Studi S1 Destinasi Pariwisata, Fakultas Pariwisata,Universitas Udayana, Jl. Dr. R. Goris, Denpasar, Bali 80232 Indonesia

\begin{abstract}
The efforts of Culture and Tourism Department as tourism stakeholder demanded to be active, to increase the tourism in Kehen Temple tourist attraction.

This research aims to determine about the efforts of Culture and Tourism Department on increasing tourists visit in Kehen Temple tourist attraction. The data collecting method used in this research are participative observation, interviews, and documentary. This research used qualitative analysis method.

From the result of this research concluded that the efforts done by Culture and Tourism Department of Bangli Regency seen from main task and function of department which written in Act Number 10 Year 2009 about tourism. Those efforts are doing fixes to tourism supporting facilities, promoting Kehen Temple as tourist attraction and held founding to local community. But according to Pokdarwis Giri Manik, the efforts held by Culture and Tourism Department felt not maximum yet.

From the conclusion then suggested for Culture and Tourism of Bangli Regency to promote Kehen Temple tourist attraction more specifically, the found ing to local community not just for Pokdarwis, and special attention on seller kiosks layout around Kehen Temple tourist attraction.
\end{abstract}

\section{Key words $\quad$ : Kehen Temple, Effort of Tourism Department, Improvements, Tourist Visit}

\section{PENDAHULUAN}

Kabupaten Bangli merupakan salah satu kabupaten di Bali yang memiliki beragam daya tarik wisata, hal tersebut sudat tercantum dalam Keputusan Bupati Bangli Nomor 556/202/2014. Keberagaman daya tarik wisata yang ada di Kabupaten Bangli menunjukkan daya tarik wisata yang ada sangat berpotensi untuk dikembangkan dan dipromosikan sehingga perlu dikelola dengan baik oleh pemerintah, desa adat serta pelaku pariwisata. Salah satu daya tarik wisata spiritual yang perlu mendapatkan perhatian adalah Pura Kehen.

Potensi wisata yang dimiliki Pura Kehen adalah keunikan arsitektur bangunannya, pintu masuk di daya tarik wisata Pura Kehen berupa candi kurung, berbeda dengan bangunan pura yang lain yang menggunakan candi bentar. Daya tarik wisata Pura Kehen juga kaya akan nilai historis dan jejak sejarah yang mengagumkan. Sistem kemasyarakatan dan upacara-upacara keagamaan juga merupakan potensi wisata yang mampu memikat hati wisatawan nusantara maupun mancanegara untuk mengunjungi destinasi wisata spiritual ini.

Kunjungan wisatawan ke daya tarik wisata Pura Kehen dari tahun 2011 sampai 2015 sempat mengalami penurunan selama tiga tahun pertama, sebelum akhirnya beranjak naik pada dua tahun berikutnya. Jumblah kunjungan wisatawan ke daya tarik wisata Pura Kehen tentunya belum dapat dikategorikan sebagai jumblah yang tinggi. Disinilah peran Dinas Kebudayaan dan Pariwisata Kabupaten Bangli sebagai penyelenggara kepariwisataan, dituntut untuk aktif dalam mengupayakan peningkatan dan pengembangan pariwisata, agar kedepannya terjadi peningkatan yang signifikan terhadap kunjungan wisatawan ke daya tarik wisata Kehen.Penelitian ini membahas upaya Dinas Kebudayaan dan Pariwisata Kabupaten Bangli untuk meningkatkan kunjungan wisatawan di daya tarik wisata Pura Kehen 


\section{TINJAUAN PUSTAKA}

Penelitian ini menggunakan beberapa pedoman konsep dan teori untuk menganalisis data yang diperoleh, yaitu:

1. Konsep Pura adalah bangunan suci yang menurut ajaran agama hindu harus ditempatkan di tempat yang suci. (Suarsana,2003:65).

2. Konsep kebijakan dapat diartikan sebagai tuntunan dalam pelaksanaan suatu kegiatan oleh suatu pemerintah (Pitana, 2009:106).

3. Konsep TUPOKSI Dinas Kebudayaan dan Pariwisata Kabupaten Bangli berdasarkan Peraturan Bupati Bangli No 23 Tahun 2008 yaitu, Merumuskan dan melaksanakan kebijakan yang terkait dengan promosi peningkatan SDM pariwisata dan anlisa prospek pasar sesuai dengan peraturan perundangan yang berlaku, Melaksanakan pembinaan, pengembangan objek dan daya tarik wisata serta perijinan usaha dan seni mutu produksi sesuai ketentuan perundangan yang berlaku .

\section{METODE}

Penelitian ini dilakukan di daya tarik wisata Pura Kehen Desa Pekraman Cempaga, Kelurahan Cempaga, Kecamatan Bangli, Kabupaten Bangli. Adapun ruang lingkup dalam penelitian ini yaitu:

1. Melaksanakan pembinaan, pengembangan objek dan daya tarik wisata serta perijinan usaha dan seni sesuai ketentuan perundangan yang berlaku

2. Merumuskan dan melaksanakan kebijakan yang terkait dengan promosi peningkatan SDM pariwisata dan anlisa prospek pasar sesuai dengan peraturan perundangan yang berlaku.

Jenis dan sumber data dalam penelitian ini menggunakan jenis data kualitatif, seperti: hasil wawancara yang ditulis dengan deskriptif, sejarah dan gambaran umum lokasi penelitian. Jenis data kuantitatif seperti jumblah kunjungan wisatawan, luas wilayah dan jumblah kios yang ada di daya tarik wisata Pura Kehen. Sumber data dalam penelitian ini adalah data primer dan data sekunder. Dalam pengumpulan data menggunakan tiga teknik yaitu observasi, wawancara dam dokumen. Untuk penentuan informan menggunakan teknik purposive sampling dimana informan yang diwawancarai sudah ditentukan dengan pertimbangan tertentu dari sebelum turun ke lapangan (Sugiyono,2014:60).

Teknik analisis data dalam penelitian ini menggunakan analisi data kualitatif meliputi kegiatan reduksi data (data reduction), penyajian data (data display), serta penarikan kesimpulan dan verifikasi data (conclusion drawing and verification).

\section{HASIL DAN PEMBAHASAN}

Pura Kehen memiliki potensi sebagai daya tarik wisata, khususnya sebagai daya tarik wisata spiritual. Potensi tersebut didukung oleh atraksi wisata alam dan budaya yang unik dan menarik minat wisatawan.

\section{a. Komponen Penunjang Kepariwisataan di Daya Tarik Wisata Pura Kehen.}

Pura kehen sudah dikembangkan dalam fungsinya sebagai daya tarik wisata, adapun komponen penunjang sebuah daya tarik wisata yaitu attraction, amenities, ancelary dan acces. Adapun komponen penunjang kepariwisataan di daya tarik wisata Pura Kehen yaitu:

1) Asessibilitas (Accsess) Perjalanan menuju daya tarik wisata Pura Kehen datap ditempuh melalui jalur utama Denpasar-Bangli, berupa jalan aspal yang cukup bagus dan bisa dilintasi oleh kendaraan roda dua, mobil, dan bus pariwisata. Jadi kenyamanan wisatawan selama berwisata di daya tarik wisata Pura Kehen terjamin dengan akses yang memadai.

2) Atraksi

a) Atraksi wisata budaya

Daya tarik wisata budaya adalah candi kurung Pura Kehen dimana pada umumnya pura besar di Bali memakai candi bentar. Posisi bale kul-kul yang bertengger di pohon beringin memberi kesan unik bagi keberadaan Pura Kehen. Kekhasan tradisi dan budaya juga dipertahankan oleh masyarakat 
pengempon Pura Kehen, dimana budaya ini juga dapat menjadi daya tarik wisata Pura kehen.

b) Atraksi wisata alam

Daya tarik wisata alam adalah keindahan Bukit bangli meliputi keasrian alam perbukitan, dengan pohon-pohon besar yang tinggi dan rindang sehingga mampu memberi kesan sejuk dan nyaman pada para pengunjung. Keadaan ini merupakan sebuah pemandangan yang layak untuk dinikmati oleh wisatawan.

3) Fasilitas

a) Areal parkir. Sekitar daya tarik wisata Pura Kehen disediakan areal parkir yang luas bagi kendaraan mobil maupun kendaraan bermotor. Parkir berada di sebelah timur daya tarik wisata Pura Kehen. Saat ini Dinas Kebudayaan dan Pariwisata Kabupaten Bangli telah memperluas areal parkir, dengan tempat yang memenuhi standar keamanan.

b) Tourist Information Center, memberikan informasi-informasi yang diperlukan wisata ketika berada di areal daya tarik wisata Pura Kehen. Tourist information Center juga menyediakan kain dan selendang, wisatawan yang ingin masuk ke areal pura dianjurkan untuk memakai kain dan selendang, hal ini dilakukan untuk tetap menajaga kesucian pura.

c) Toilet, fasilitas dasar penunjang kepariwisataan di daya tarik wisata adalah ketersediaan toilet yang sesuai standar kebersihan. Daya tarik wisata Pura Kehen menyediakan toilet yang berada di sebelah barat daya pura. Toilet dibedakan menjadi toilet khusus wanita dan pria, dan menurut observasi yang dilakukan toilet di daya tarik wisata Pura Kehen sudah memenuhi standar kebersihan.

d) Loket / Tempat pemungutan restribusi, Tempat pemungutan restribusi terletak di sebelah gapura utama daya tarik wisata Pura Kehen. Tempat pemungutan retribusi dijaga oleh dua pegawai pemungut tiket yang ditugaskan oleh Dinas Kebudayaan dan Pariwisata Kabupaten Bangli. Harga tiket untuk wisatawan asing dan luar pulau Bali adalah Rp. 30.000-, sedangkan untuk wisatawan lokal pulau Bali hanya berupa dana punia seiklasnya, dan bagi umat yang ingin melakukan persembahyangan tidak dipungut biaya apapun.

e) Kios berada di sebelah utara dan selatan parkir terdapat kurang lebih 23 kios yang sebagian besar menjual souvenir khas Bali.Souvenir yang dijual di kioskios tersebut seperti patung kayu, kain bali dan topeng khas Bali. Dari 23 kios yang ada hanya tersisa kurang lebih 10 kios yang buka setiap harinya, dan tiga diantaranya menjual minuman dan makanan ringan.

4) Kelembagaan (Ancillary) kelembagaan kepariwisataan di daya tarik wisata pura kehen adalah Kelompok Sadar Wisata Wiri Manik. Kelompok ini terdiri dari tokoh agama, tokoh masyarakat, praktisi pariwisata dan kalangan generasi muda di Lingkungan Pekuwon Kelurahan Cempaga Bangli. Kelompok Sadar Wisata Giri Manik didirikan pada Sabtu Wage Julungwangi, 10 Mei 2014, dan di sahkan dengan Surat Keputusan Bupati Bangli

\section{b. Upaya Dinas Dalam Meningkatkan Kunjungan Wisatawan}

upaya yang sudah dilakukan adalah sebagai berikut:

1) Menfasilitasi daya tarik wisata Pura Kehen, fasilitas pendukung kepariwisataan di daya tarik wisata Pura Kehen sangat berpengaruh pada kepuasan wisatawan. Oleh sebab itu fasilitas yang memenuhi standar dalam berjalannya suatu kepariwisataan di daya tarik wisata perlu diperhatikan secara 
khusus. Perbaikan fasilitas di daya tarik wisata Pura Kehen yang tengah dilakukan adalah :

a) Parkir adalah fasilitas yang sangat diperlukan oleh wisatawan, parkir yang memadai dengan keamanan yang memenuhi standar akan menciptakan kesan aman dan nyaman bagi wisatawan yang berkunjung di daya tarik wisata Pura Kehen. Tahun 2015 Dinas Kebudayaan dan Pariwisata Kabupaten Bangli melakukan perluasan areal parkir demi kenyamanan wisatawan di daya tarik wisata Pura Kehen. Parkir yang semula hanya ada di sebelah timur tourist information center, sekarang diperluas keutara

b) Loket/ Tempat pemungutan restribusi di tahun 2015 Dinas Kebudayaan dan Pariwisata Kabupaten Bangli melakukan perbaikan di sekitar tempat pemungutan restribusi. Perbaikan tersebut meliputi pembangunan gapura, perbaikan bangunan pemungutan restribusi, dan hiasan patung dan lampu taman. Perbaikan ini bertujuan untuk mendapatkan kesan pertama yang baik bagi wisatawan yang berkunjung ke daya tarik wisata Pura Kehen.

2) Melakukan Promosi Daya Tarik Wisata Pura Kehen.

a) Dua website yang dikelola oleh Dinas Kebudayaan dan Pariwisata Kabupaten Bangli sebagai media promosi yaitu, disbudpar.banglikab.go.id dan www.baturglobalgeopark.com.

Media sosial yang dikelola oleh Dinas Kebudayaan dan Pariwisata Kabupaten Bangli saat ini hanya pada media facebook Batur Global Geopark

b) Promosi dengan media offline tersebut berupa pembuatan flatbook
Bangli Regency Tourist Information, brosur, baliho selamat datang ke daya tarik wisata Pura Kehen, mengikuti dan membuat event pariwisata di tingkat nasional maupun internasional

3) Pembinaan Kepada Kelompok Sadar Wisata Tentang Kepariwisataan

Peran kelompok sadar wisata dalam kelangsungan kegiatan kepariwisataan tersebut sangat penting, maka pemerintah dalam hal ini Dinas Kebudayaan dan Pariwisata Kabupaten Bangli melakukan beberapa upaya untuk meningkatkan kegiatan kelompok sadar wisata yang ada di kabupaten Bangli. Beberapa hal yang dilakukan oleh pemerintah antara lain, melakukan lomba kelompok sadar wisata, pembinaan dan penyuluhan kelompok sadar wisata, pelatihan SDM dan pariwisata di tingkat kelompok sadar wisata.

Pembinaan kelompok sadar wisata ini diharapkan dapat menjadi upaya penguatan kapasitas, peran inisiatif masyarakat sebagai subjek maupun penerima manfaat dalam pengembangan kepariwistaan di daerahnya.

\section{SIMPULAN DAN SARAN}

\section{A. Simpulan}

Dinas Kebudayaan dan Pariwisata dalam meningkatkan kunjungan wisatawan adalah dilakukan dengan memfasilitasi daya tarik wisata, mempromosikan daya tarik wisata Pura Kehen dan melakukan pembinaan kepada kelompok sadar wisata. Memfasilitasi daya tarik wisata Pura Kehen dengan melakukan perbaikan fasilitas penunjang kepariwisataan. Melakukan promosi daya tarik wisata Pura Kehen dengan media promosi online dan offline. Melakukan pembinaan kepada kelompok sadar wisata tentang kepariwisataan dan menekankan pentingnya sapta pesona dalam pengembangan daya tarik wisata

\section{B. Saran}

Berdasarkan hasil dan pembahasan tersebut, maka dapat diajukan beberapa saran antara lain : 
1) Pengelolaan yang baik terkait kios-kios yang ada di sekitar daya tarik wisata Pura Kehen. Pengelolaan dapat dilakukan dengan musyawarah bersama terakit kebijakan terhadap kios-kios yang tutup. Hal ini harus mendapat perhatian khusus, agar kenyamanan dan keindahan daya tarik wisata Pura Kehen dapat menjadi kesan yang memancing niat wisatawan untuk datang kembali.

2) Pemasaran Pura Kehen sebagai daya tarik wisata lebih ditekankan, agar nantinya tidak lagi digabung dengan daya tarik wisata lain yang ada di Kabupaten Bangli. Pemasaran yang lebih spesifik nantinya dapat menyasar pangsa pasar yang tepat.

3) Pembinaan dan sosialisasi pada masayarakat lokal bukan hanya terbatas pada Kelompok Sadar Wisata, namun kepada masyarakat lokal yang pada dasarnya lebih tau potensi di daerahnya. Selian itu agar pariwisata yang ada di daya tarik wisata Pura kehen dapat dirasakan dampak ekonominya bagi masyarakat lokal.

\section{Daftar Pustaka}

Asri,Karmi.2000. Pura Kehen di Desa Pakraman Cempaga, Bangli, Bali (Sejarah Struktur dan Fungsinya Sebagai Sumber Belajar Sejarah).Singaraja. Universitas Pendidikan Ganesha

Pitana, I Gde dan I Ketut Surya Diarta. 2009. Pengantar Ilmu Pariwisata. Yogyakarta: ANDI.

Parikesit Widiatedja. 2011. Kebijakan Liberalisasi Pariwisata Kontruksi Konsep Ragam Masalah dan Alternatif Solusi. Denpasar: Udayana University Press.

Peraturan Daerah Provinsi Bali Nomor 4 Tahun 2011 Tentang Organisasi dan Tata Kerja Perangkat Daerah

Peraturan Bupati Bangli Nomor 33 Tahun 2008 Tentang Rincian Tugas Jabatan Struktural Pada Dinas Kebudayaan dan Pariwisata Kabupaten Bangli

Sugiyono. 2009. Metode Penelitian Bisnis (Pendekatan Kuantitatif, Kualitatif, dan R\&D). Alfabeta. Bandung

Undang-undang Republik indonesia Nomor 10 Tahun 2009 Tentang Kepariwisataan

Yusuf, Muri. 2013. Metode Penelitian Kuantitaif, Kualitatif, Penelitian Gabungan. Jakarta : Prenada Media Group.

Yoeti, Oka A. 1997. Perencanaan dan Pengembangan Pariwisata. Bandung: PT Angkasa. 